Jurnal As-Salam, 2(2) Mei - Agustus 2018
(Print ISSN 2528-1402, Online ISSN 2549-5593)

\title{
PENERAPAN MODEL PEMBELAJARAN KOOPERATIF GROUP INVESTIGATION UNTUK MENINGKATKAN HASIL BELAJAR SEJARAH SISWA PADA MATERI PRINSIP-PRINSIP PENELITIAN SEJARAH DI KELAS X SMA NEGERI 1 SUNGAI MAS
}

\author{
T. Kamarisal \\ SMA Negeri 1 Sungai Mas \\ Email: risal.tms@gmail.com
}

\begin{abstract}
Abstrak. Hasil belajar siswa di sekolah masih banyak yang mengalami masalah yang disebabkan oleh tidak tercapainya ketuntasan minimal yang diterapkan. Hal disebabkan oleh berbagai faktor, diantaranya masih ada guru yang belum mampu menggunakan metode yang benar. Penggunaan metode sering kali dilakukan dengan pemberian tugas dan latihan serta ceramah. Metode ini tidak dapat mengeksplor kemampuan motorik siswa dan kreativitas berpikirnya. Peneltian ini dilaksanakan selama 3 bulan dari bulan Januari sampai dengan Maret 2017 di SMA Negeri 1 Sungai Mas yang bertujuan untuk mengetahui peningkatan hasil belajar siswa kelas X pada materi Prinsip-prinsip Penelitian Sejarah pelajaran Sejarah dengan menggunakan model Group Investigation (GI) pada SMA Negeri 1 Sungai Mas. Penelitian ini dilaksanakan di kelas X Negeri 1 Sungai Mas yang jumlah siswanya 30 orang siswa sebagai subjek penelitian. Data diperoleh menggunakan tes dan non tes. Data dianalis secara deskriptif dengan cara membandingkan antara siklus I dan siklus II. Hasil penelitian menunjukkan bahwa terdapat peningkatan hasil belajar siswa kelas X Negeri 1 Sungai Mas pada materi Prinsip-prinsip Penelitian Sejarah dengan menggunakan model GI dengan hasil pada siklus I dari 30 orang siswa terdapat $19(63,33 \%)$ orang yang yang tuntas secara klasikal, sedangkan setelah siklus II meningkat menjadi 28 orang siswa atau $(93,33 \%)$ yang tuntas secara klasikal.
\end{abstract}

Kata Kunci: Kooperatif GI, hasil belajar.

\section{Pendahuluan}

Pendidikan merupakan hal yang sangat penting dalam kehidupan manusia. Perintah menuntut ilmu dimulai semenjak manusia tersebut berada dalam ayunan hingga manusia tersebut sampai menemui ajalnya. Dalam mempersiapkan peserta didik yang handal, Pemerintah memberlakukan kurikulum yang berbasis pada kepentingan sekolah. Kurikulum itu dikenal dengan nama Kurikulum Tingkat Satuan Pendidikan (KTSP). Kelebihan KTSP antara lain mendorong terwujudnya otonomi sekolah dalam penyelenggaraan pendidikan dan mendorong para guru, kepala sekolah, dan pihak manajemen sekolah untuk semakin meningkatkan kreativitasnya dalam penyelenggaraan program-program pendidikan.

Guru sebagai pendidik memegang peran penting baik dalam menyusun maupun melaksanakan kegiatan pembelajaran. Pemberian pengetahuan kepada anak didik merupakan proses belajar mengajar yang dilakukan oleh pendidik di sekolah menggunakan cara-cara atau metode tertentu untuk menumbuhkan motivasi belajar peserta didik dan memperkuat daya ingat peserta didik terhadap materi yang diajarkan. Metode mengajar adalah suatu pengetahuan tentang cara-cara mengajar yang dipergunakan oleh seorang pendidik untuk menyajikan pelajaran kepada anak didik di dalam kelas, baik secara individual maupun secara kelompok, agar pelajaran itu dapat diserap, dipahami dan dimanfaatkan oleh anak didik dengan baik (Johar dkk, 2006: 97- 
98). Salah satu cara untuk meningkatkan minat peserta didik dalam kegiatan belajar mengajar yaitu dengan mengembangkan strategi pembelajaran seperti menggunakan model-model pembelajaran yang tepat, sesuai dengan materi pelajaran. Pemilihan model pembelajaran yang kurang tepat akan berpengaruh terhadap prestasi belajar yang rendah, peserta didik bersikap pasif, dan pendidik cendrung mendominasi sehingga peserta didik kurang mandiri (Suwiyadi, 2007). Pemilihan model pembelajaran yang benar akan membantu siswa mencapai standar kompetensi dari materi yang diajarkan dan membantu guru mengembangkan kompetensi yang dimilikinya. Zulmaulida, dkk (2014) mengatakan "Materi pembelajaran yang dipilih memiliki relevansi (keterkaiatan) dengan pencapaian standar kompetensi dan kompetenasi dasar melalui proses-proses yang tepat".

Group investigation merupakan salah satu model pembelajaran kooperatif. Model ini sering dipandang sebagai model yang paling kompleks dibandingkan dengan model lain dalam pembelajaran kooperatif (Padmadewi dalam Santosa, 2007. Group Investigation merupakan salah satu bentuk model pembelajaran kooperatif yang menekankan pada partisipasi dan aktivitas siswa untuk mencari sendiri materi (informasi) pelajaran yang akan dipelajari melalui bahan-bahan yang tersedia, misalnya dari buku pelajaran atau siswa dapat mencari melalui internet. Siswa dilibatkan sejak perencanaan, baik dalam menentukan topik maupun cara untuk mempelajarinya melalui investigasi. Tipe ini menuntut para siswa untuk memiliki kemampuan yang baik dalam berkomunikasi maupun dalam keterampilan proses kelompok. Model Group Investigation dapat melatih siswa untuk menumbuhkan kemampuan berfikir mandiri. Keterlibatan siswa secara aktif dapat terlihat mulai dari tahap pertama sampai tahap akhir pembelajaran (Sudrazat, 2009).

Beberapa hasil penelitian tentang penerapan model pembelajaran group investigation (GI) memiliki dampak positif terhadap prestasi siswa. Selain dapat meningkatkan prestasi belajar, siswa juga mampu menumbuhkan kemampuan berpikir, kerjasama dan mengembangkan sikap sosial siswa. Muhibbah (2009) menyatakan bahwa penerapan model pembelajaran GI dapat memberikan pengaruh yang baik terhadap prestasi siswa, siswa yang diajarkan dengan model GI mempunyai nilai rata-rata yang lebih tinggi dibandingkan siswa yang diajar dengan metode ceramah. Begitu juga menurut Mcklar (2008) mengemukakan bahwa dengan menerapkan metode pembelajaran GI menujukkan hasil yang positif, motivasi dan hasil belajar siswa terlihat peningkatan yang signifikan dari siklus I ke siklus II baik dari segi aktivitas dan hasil pembelajaran. Jadi penerapan model pembelajaran GI memiliki dampak positif terhadap prestasi siswa.

Berdasarkan pengamatan peneliti selama menjadi guru di SMA Negeri 1 Sungai Mas, pembelajaran Sejarah di SMA tersebut masih kurang optimal untuk dapat menumbuhkan keterampilan dan keaktifan siswa karena dilihat dari nilai rapor dan dari nilai-nilai tugas yang telah diberikan. Pada saat pembelajaran berlangsung, siswa cenderung pasif jarang mengemukakan pendapat. Untuk itu, guru harus berusaha agar siswa tidak hanya belajar memahami konsep-konsep dan prinsip-prinsip, tetapi siswa juga mengalami proses belajar dan dapat memecahkan berbagai masalah yang dihadapi dalam belajar melalui model pembelajaran Group Investigation. 


\section{Landasan Teori}

\section{A. Hasil Belajar}

Hasil belajar adalah pola-pola perbuatan, nilai-nilai, pengertian-pengertian, sikapsikap, apresiasi dan keterampilan (Suprijono, 2009). Hasil belajar merupakan perubahan perilaku yang diperoleh pembelajar setelah mengalami aktivitas belajar. Perolehan aspekaspek perubahan perilaku tersebut tergantung pada apa yang dipelajari oleh pembelajar (Anni, 2007). Hasil belajar siswa dalam hal ini meliputi tiga aspek, yaitu aspek kognitif,aspek afektif dan aspek psikomotorik. (1) aspek kognitif, kemampuan kognitif yang meliputi: pengetahuan, pemahaman, penerapan, analisis, sintesis, dan evaluasi. (2) Aspek afektif, kemampuan afektif meliputi penerimaan, partisipasi, penilaian,dan penentuan sikap, organisasi, dan pembentukan pola hidup. (3) Aspek psikomotorik, kemampuan psikomorik meliputi: persepsi, kesiapan, gerakan terbimbing, gerakan terbiasa, gerakan kompleks, gerakan penyesuaian dan kreativitas (Hamalik, 2003).

Menurut Bloom, sebagaimana dikutip oleh Anni (2007:7), hasil belajar mencakup kemampuan tiga ranah belajar, yaitu:

1. Ranah Kognitif

Ranah kognitif berkaitan dengan hasil berupa pengetahuan, kemampuan dan kemahiran intelektual. Ranah kognitif mencakup kategori pengetahuan, pemahaman, penerapan, analisis,sintesis, penilaian.

\section{Ranah Afektif}

Tujuan pembelajaran ranah afektif berhubungan dengan perasaan, sikpa, minat, dan nilai. Kategori ranah afektif meliputi penerimaan, penanggapan, penilaian, pengorganisasian, dan pembentukan pola hidup.

\section{Ranah Psikomotorik}

Tujuan pembelajaran ranah psikomotorik menunjukkan adanya kemampuan fisik seperti keterampilan motorik dan syaraf, manipulasi objek, dan koordinasi syaraf. Kategori ranah psikomotorik meliputi persepsi, kesiapan, gerakan terbimbing, gerakan terbiasa, gerakan kompleks, penyesuaian, dan kreativitas.

Hasil belajar yang dikaji dalam penelitian ini adalah perubahan pada diri siswa yang ranah kognitif yang dinilai dengan soal tes, ranah afektif yang meliputi tanggung jawab, mandiri, menjadi pendengar yang baik, menghargai pendapat orang lain dan keberanian menyampaikan pendapat dan ranah psikomotorik yang meliputi aktif dalam diskusi, mengajukan pertanyaan yang mendidik, kemampuan menjawab pertanyaan yang diajukan guru atau siswa lainnya selama proses diskusi.

\section{B. Pembelajaran Kooperatif Group Investigation (GI)}

Group investigation merupakan salah satu model pembelajaran kooperatif. Model ini sering dipandang sebagai model yang paling kompleks dibandingkan dengan model lain dalam pembelajaran kooperatif (Padmadewi dalam Santosa, 2007). Group Investigation merupakan salah satu bentuk model pembelajaran kooperatif yang menekankan pada partisipasi dan aktivitas siswa untuk mencari sendiri materi (informasi) pelajaran yang akan dipelajari melalui bahan-bahan yang tersedia, misalnya dari buku pelajaran atau siswa dapat mencari melalui internet. Siswa dilibatkan sejak perencanaan, baik dalam menentukan topik maupun cara untuk mempelajarinya melalui investigasi. Tipe ini menuntut para siswa untuk memiliki kemampuan yang baik dalam 
berkomunikasi maupun dalam keterampilan proses kelompok. Model Group Investigation dapat melatih siswa untuk menumbuhkan kemampuan berfikir mandiri. Keterlibatan siswa secara aktif dapat terlihat mulai dari tahap pertama sampai tahap akhir pembelajaran (Johar, 2006).

\section{Langkah-langkah Model Pembelajaran Group Investigation (GI)}

Menurut Sharan dalam Widodo (2009) yang menyatakan bahwa langkah-langkah model pembelajaran Group Investigation adalah sebagai berikut:

a) Guru membagi kelas dalam beberapa kelompok heterogen.

Para siswa memilih berbagai subtopik dalam suatu wilayah masalah umum yang biasanya digambarkan terlebih dahulu oleh guru. Para siswa selanjutnya diorganisasikan menjadi kelompok-kelompok yang berorientasi pada tugas (task oriented groups) yang beranggotakan 2 hingga 6 orang. Komposisi kelompok heterogen baik dalam jenis kelamin, etnik maupun kemampuan akademik. Siswa dibagi menjadi 5 kelompok dimana setiap kelompoknya terdiri dari 5 orang dengan materi yang berbeda yang telah dipilih sendiri oleh siswa

b) Merencanakan Kerjasama

Para siswa bersama guru merencanakan berbagai prosedur belajar khusus, tugas dan tujuan umum yang konsisten dengan berbagai topik dan subtopik yang telah dipilih dari langkah a) diatas. Disini siswa merencanakan kerjasama dengan anggota satu tim untuk menyelesaikan masalah yang telah diberikan

c) Implementasi

Para siswa melaksanakan rencana yang telah dirumuskan pada langkah b). Guru menjelaskan maksud pembelajaran dan tugas kelompok. Guru memanggil ketua kelompok dan setiap kelompok mendapat tugas satu materi/tugas yang berbeda dari kelompok lain. Masing-masing kelompok membahas materi yang sudah ada secara kooperatif yang bersifat penemuan. pembelajaran harus melibatkan berbagai aktivitas dan keterampilan dengan variasi yang luas dan mendorong para siswa untuk menggunakan berbagai sumber baik yang terdapat di dalam maupun di luar sekolah, adapun sumber yang dapat mereka gunakan yaitu baik itu bahan dari buku, internet dan yang terdapat dalam kehidupan sehari-hari. Guru secara terus-menerus mengikuti kemajuan tiap kelompok dan memberikan bantuan jika diperlukan

d) Setelah selesai diskusi, juru bicara kelompok menyampaikan hasil pembahasan kelompok. Para siswa menganalisis dan mensintesis berbagai informasi yang diperoleh pada langkah c) dan merencanakan agar dapat diringkaskan untuk membuat suatu penyajian yang menarik yang akan ditampilkan didepan kelas baik dalam bentuk power point atau dalam bentuk gambar yang ditempel dikertas karton

e) Penyajian Hasil Akhir

Semua kelompok menyajikan suatu presentasi yang menarik dari berbagai topik yang telah dipelajari agar semua siswa dalam kelas saling terlibat dan mencapai suatu perspektif yang luas mengenai topik tersebut. Presentasi kelompok dikoordinir oleh guru. Guru memberikan penjelasan atau pengutan materi secara singkat sekaligus memberi kesimpulan. 
f) Evaluasi dan penutup.

Guru beserta siswa melakukan evaluasi mengenai kontribusi tiap kelompok terhadap pekerjaan kelas sebagai suatu keseluruhan. Evaluasi dapat mencakup tiap siswa secara individu atau kelompok, atau keduanya.

\section{Metode Penelitian}

Penelitian ini menggunakan metode deskriptif kualitatif, yang dilaksanakan selama 3 bulan, mulai dari bulan Januari sampai dengan bulan Maret 2017. Penelitian dilaksanakan di SMA Negeri 1 Sungai Mas, selain itu salah satu tujuan yang dari penelitian ini adalah untuk memperbaiki proses pembelajaran mata pelajaran Sejarah khususnya pada kompetensi dasar mengenal materi Prinsip-prinsip Penelitian Sejarah terhadap informasi. Sumber data dalam penelitian ini adalah siswa, sebagai subyek penelitian. Data yang dikumpulkan dari siswa meliputi data hasil tes tertulis. Tes tertulis dilaksanakan pada setiap akhir siklus yang terdiri atas materi Prinsip-prinsip Penelitian Sejarah terhadap informasi. Selain siswa sebagai sumber data, penulis juga menggunakan teman sejawat sesama guru pelajaran Sejarah sebagai sumber data. Dalam penelitian ini pengumpulan data menggunakan teknik tes dan non tes. Tes tertulis digunakan pada akhir siklus I dan siklus II. Sedangkan Teknik non tes meliputi teknik observasi dan dokumentasi. Observasi digunakan pada saat pelaksanaan penelitian tindakan kelas kemampuan memahami materi Prinsip-prinsip Penelitian Sejarah pada siklus I dan siklus II. Sedangkan teknik dokumentasi digunakan untuk mengumpulkan data khususnya nilai mata pelajaran Sejarah. Analisis data yang digunakan dalam penelitian ini adalah teknik analisis dekskriptif, yang meliputi:

1. Analisis deskriptif komparatif hasil belajar dengan cara membandingkan hasil belajar pada siklus I dengan siklus II dan membandingkan hasil belajar dengan indikator pada siklus I dan siklus II.

2. Analisis deskriptif kualitatif hasil observasi dengan cara membandingkan hasil observasi dan refleksi pada siklus I dan siklus II.

Penelitian ini merupakan penelitian tindakan kelas (classroom action research) yang ditandai dengan adanya siklus, adapun dalam penelitian ini terdiri atas 2 siklus. Setiap siklus terdiri atas perencanaan, pelaksanaan, pengamatan dan refleksi. Analisi hasil belajar siswa dihitung menggunakan rumus Purwanto (190):

$$
N=\frac{\text { Jumlah Jawaban Benar }}{\text { Jumlah Soal }} \times 100 \%
$$

Tahapan pelaksanaan setiap siklus seperti berikut:

1. Siklus I

a. Perencanaan (planning), terdiri atas kegiatan:

1) penyusunan rencana pelaksanaan pembelajaran (RPP);

2) penyiapan skenario pembelajaran.

b. Pelaksanaan (acting), terdiri atas kegiatan;

1) pelaksanaan program pembelajaran sesuai dengan jadwal,

2) proses pembelajaran dengan menerapkan pembelajaran model GI pada kompetensi dasar Prinsip-prinsip Penelitian Sejarah terhadap informasi,

3) secara klasikal menjelaskan strategi dalam pembelajaran GI dilengkapi lembar kerja siswa, 
4) mengadakan observasi tentang proses pembelajaran,

5) mengadakan tes tertulis,

6) penilaian hasil tes tertulis.

c. Pengamatan (observing), yaitu mengamati proses pembelajaran dan menilai hasil tes sehingga diketahui hasilnya. Atas dasar hasil tersebut digunakan untuk merencanakan tindak lanjut pada siklus berikutnya.

d. Refleksi (reflecting), yaitu menyimpulkan pelaksanaan hasil tindakan pada siklus I.

2. Siklus II

a. Perencanaan (planning), terdiri atas kegiatan:

a. penyusunan rencana pelaksanaan pembelajaran (RPP);

b. penyiapan skenario pembelajaran.

b. Pelaksanaan (acting), terdiri atas kegiatan;

a. pelaksanaan program pembelajaran sesuai dengan jadwal,

b. pembelajaran model GI pada kompetensi dasar mengenai Prinsip-prinsip Penelitian Sejarah terhadap informasi,

c. siswa untuk menerapkan model pembelajaran $G I$, diikuti kegiatan kuis

d. mengadakan observasi tentang proses pembelajaran,

e. mengadakan tes tertulis,

f. penilaian hasil tes tertulis.

c. Pengamatan (observing), yaitu mengamati proses pembelajaran dan menilai hasil tes serta hasil praktek sehingga diketahui hasilnya,

d. Refleksi (reflecting), yaitu menyimpulkan pelaksanaan hasil tindakan pada siklus II.

\section{Hasil dan Pembahasan}

Siklus I

a. Perencanaan

Perencanaan tindakan dalam siklus I pertama dimulai dengan pemilihan materi dan penyusunan rencana pelasaksanaan pembelajaran dilakukan pada kompetensi dasar komentar terhadap informasi. Selanjutnya disusun dalam rencana pelaksanaan pembelajaran (RPP). Tema yang dipilih yaitu mendata informasi dari sebuah artikel dan merumuskan pokok persoalan. RPP yang disusun berdurasi 2 x 45 menit, artinya setiap RPP disampaikan dalam 1 kali tatap muka. Pada tahap ini juga dilakukan pembentukan kelompok-kelompok belajar, siswa dalam satu kelas dibagi menjadi 6 kelompok kecil dengan memperhatikan heterogenitas baik kemampuan, gender.

b. Pelaksanaan Tindakan

1) Pelaksanaan Tatap Muka

Tatap muka dilakukan pada materi komentar terhadap informasi. Model pembelajaran yang digunakan adalah GI dengan panduan buku pelajaran dengan langkah-langkah sebagai berikut;

a) Guru secara klasikal menjelaskan strategi pembelajaran yang harus dilaksanakan siswa.

b) Secara kelompok siswa telah medata informasi dari sebuah artikel yang sudah ditugaskan pada pertemuan sebelumnya. 
c) Secara kelompok siswa berdiskusi kembali menyelesaikan tugas yang diberikan.

d) Perwakilan kelompok mempresentasikan hasil kerja kelompok yang telah dikerjakan.

e) Guru memberi umpan balik hasil pemahaman siswa terhadap materi yang dipelajari dengan mengadakan evaluasi berupa tes.

f) Guru menilai hasil evaluasi.

g) Guru memberikan tindak lanjut.

Pembelajaran yang dilaksanakan menunjukkan bahwa aktivitas siswa selama belajar lebih kepada diskusi dalam menemukan masalah. Siswa berperan aktif dan bertanggung jawab dalam memberikan komentar terhadap informasi yang diberikan guru. Partisipasi siswa membuat suasana kelas menjadi riuh dan terlihat tidak membosankan.

2) Wawancara

Wawancara dilaksanakan pada saat pembelajaran sudah selesai dilaksanakan. Kegiatan wawancara dilaksanakan oleh guru terhadap beberapa anggota kelompok. Wawancara diperlukan untuk mengetahui pendapat siswa tentang proses pembelajaran yang sudah berlangsung.. Hasil wawancara digunakan untuk refleksi. Hasil wawancara menunjukkan bahwa siswa pada setiap kelompok mampu mengikuti pembelajaran dengan baik walaupun terjadi sedikit perbedaan pendapat pada saat diskusi.

c) Pengamatan atau Observasi

Observasi dilaksanakan berbarengan dengan pelaksanaan pembelajaran, dalam hal ini observasi dilakukan oleh 2 (dua) observer yaitu peneliti dengan teman sejawat pada SMA Negeri 1 Labuhanhaji Aceh Selatan. Observasi dilaksanakan untuk mengetahui secara detail keaktifan, kerjasama, kecepatan dan ketepatan siswa dalam memahami materi komentar terhadap informasi. Hasil observasi digunakan sebagai bahan refleksi dan untuk merencanakan rencana tindakan pada siklus II.

Kegiatan pengamatan atau observasi dilakukan bersamaan dengan pelaksanaan tindakan dan diperoleh data yang bahwa pada tahap ini pelaksanaan tindakan sudah sesuai dengan rencana yang sudah dibuat dengan sedikit perbaikan pada manajemen waktu diskusi dan proses menyatakan pendapat.

Hasil tes seteleh siklus I selesai diperoleh nilai A (sangat baik) adalah 2 siswa (6,66 $\%$ ), sedangkan yang mendapat nilai B (baik) adalah 9 siswa atau (30,0 \%), sedangkan dari jumlah 30 siswa yang masih mendapatkan nilai $\mathrm{C}$ (cukup) sebanyak 8 siswa (26,66 \%), sedangkan yang mendapat nilai D (kurang) ada 6 siswa (20,00\%), sedangkan yang mendapat nilai $\mathrm{E}$ (sangat kurang) ada 5 siswa $(16,66 \%)$.

d) Refleksi

Berdasarkan hasil tes pada siklus I dapat dilihat masih ada siswa yang masih di bawah Kriteria ketuntasan Minimal. Hasil ini diakibatkan proses penyampaian informasi dari kawan sekelompok tidak maksimal. Hal lain yang menyebabkan ini karena kemampuan memahami masalah oleh siswa masih terlalu beragam. Tidak semua siswa mampu menyampaikan pendapat dengan benar. Oleh karena itu, diperlukan upaya perbaikan pembelajaran pada siklus II. 


\section{Siklus II}

a. Perencanaan

Perencanaan tindakan dalam siklus II pada dilakukan berdasarkan hasil temuan dan refleksi pada siklus I. Perbaikan yang dilakukan yaitu menyesuaikan alokasi waktu yang diperlukan sehingga penyampaian materi bisa berlangsung secara maksimal. Perbaikan lainnya yaitu guru lebih berperan dalam memfasilitasi duskusi siswa, guru dalam hal ini menjadi moderator dan mengarahkan siswa untuk menggali masalah dari informasi yang diberikan. Atas dasar materi pelajaran tersebut kemudian dilanjutkan dengan pembuatan rencana pelaksanaan pembelajaran (RPP). Alokasi waktu yang dibutuhkan untuk kegiatan tersebut adalah 2 x 45 menit.

b. Pelaksanaan Tindakan

1) Pelaksanaan Tatap Muka

Tatap muka dilakukan pada materi komentar terhadap informasi. Model pembelajaran yang digunakan adalah GI dengan panduan buku pelajaran dengan langkah-langkah sebagai berikut;

a) Guru memberikan evaluasi atas kegiatan pembelajaran pada siklus I.

b) Guru melatih siswa untuk berani menyampaikan kritik terhadap artikel atau informasi didepan kelas.

c) Membimbing siswa untuk merangkum pelajaran.

d) Guru memberikan evaluasi dengan tes.

e) Guru menilai hasil evaluasi.

Pada pelaksanaan pembelajaran pada siklus II siswa masih belajar secara kelompok, perbedaan yang signifikan dengan pelaksanaan pada siklus I yaitu, pada siklus II ini siswa sudah mulai terarah dalam menggali informasi dari masalah yang ada dan menyampaikan kritik yang baik terhadap informasi yang diperoleh kelompok lainnya.

2) Wawancara

Wawancara dilaksanakan pada saat pembelajaran sudah selesai dilaksanakan. Wawancara dilaksanakan pada saat siswa melakukan kegiatan pembelajaran. Wawancara dilakukan untuk mengidentifikasi kesulitan siswa selama proses pembelajaran berlangsung. Hasil wawancara menunjukkan bahwa siswa sudah beradaptasi dengan baik dan dapat mengikuti pembelajaran sesuai dengan arahan guru.

\section{e. Pengamatan atau Observasi}

Kegiatan pengamatan atau observasi dilakukan bersamaan dengan pelaksanaan tindakan dan diperoleh data yang bahwa pada tahap ini pelaksanaan tindakan sudah sesuai dengan rencana yang sudah dibuat. Observasi dilakukan oleh 2 (dua) observer yaitu peneliti dan teman sejawat di kelas $X_{2}$ SMA Negeri 1 Labuhanhaji Aceh Selatan.

Hasil tes siklus II diperoleh nilai sangat baik (A) adalah $16,66 \%$ atau 5 siswa, sedangkan yang terbanyak yaitu yang mendapat nilai baik (B) adalah 50,00 \% atau 15 siswa. Dan yang mendapat nilai C (cukup) adalah 26,66\% atau sebanyak 8 siswa. Sedangkan yang mendapat nilai $\mathrm{D}$ ada $6,66 \%$ atau 2 siswa dan E tidak ada. 


\section{d. Refleksi}

Berdasarkan nilai hasil siklus II dapat diketahui bahwa pembelajaran menggunakan model GI dapat meningkatkan hasil belajar siswa. Hasil belajar siswa setelah pembelajaran menunjukkan bahwa seluruh siswa sudah tuntas belajar secara klasikal, sehingga siklus ini tidak perlu dilanjutkan.

Nilai mata pelajaran Sejarah pada materi Prinsip-prinsip Penelitian Sejarah masih rendah. Salah satunya penyebabnya adalah karena siswa hanya diajarkan dengan metode pembelajaran konvensional yang monoton. Berdasarkan tingkat ketuntasan belajar siswa pada tes siklus I tersebut menunjukkan bahwa yang mencapai nilai A (sangat baik) adalah 2 siswa (6,66\%), sedangkan yang mendapat nilai B (baik) adalah 9 siswa atau (30,0\%), sedangkan dari jumlah 30 siswa yang masih mendapatkan nilai C (cukup) sebanyak 8 siswa $(26,66 \%)$, sedangkan yang mendapat nilai D (kurang) ada 6 siswa (20,00\%), sedangkan yang mendapat nilai E (sangat kurang) ada 5 siswa $(16,66 \%)$.

Proses pembelajaran pada siklus I sudah menunjukkan adanya perubahan, meskipun belum semua siswa terlibat aktif dalam kegiatan pembelajaran. Hal ini disebabkan karena siswa masih baru dalam melakukan diskusi kelompok untuk menggali masalah dari informasi yang ada. Namun secara keseluruhan aktivitas siswa selama pembelajaran dengan model GI menunjukkan peningkatan yang signifikan. Siswa sudah mampu menyampaikan informasi dan mengomentari informasi dari kelompok lain dengan baik. Aktivitas ini menunjukkan interaksi siswa dengan siswa lainnya semakin baik..

Hasil belajar setelah perlakuan dengan penerapan model GI pada siklus I menyebabkan adanya perubahan walau belum optimal, hal ini ditandai dengan peningkatan jumlah siswa yang mencapai ketuntasan belajar. Hasil tes akhir siklus I ternyata lebih baik dibandingkan dengan hasil tes pada kondisi awal atau sebelum dilakukannya tindakan.

Hasil dari refleksi siklus I diperoleh kesimpulan bahwa penerapan model GI mampu meningkatkan ketuntasan belajar siswa yaitu dari 15 siswa belum tuntas pada pra siklus menjadi 6 siswa yang belum tuntas pada siklus I. Pada siklus I ini belum semua siswa mencapai ketuntasan, hal ini disebabkan oleh karena kemampuan siswa untuk menggali informasi masih terlalu beragam.

Setelah perbaikan yang dilakukan untuk pelaksanaan siklus II diketahui bahwa yang mendapatkan nilai sangat baik (A) adalah $16,66 \%$ atau 5 siswa, sedangkan yang terbanyak yaitu yang mendapat nilai baik (B) adalah 50,00\% atau 15 siswa. Dan yang mendapat nilai $\mathrm{C}$ (cukup) adalah $26,66 \%$ atau sebanyak 8 siswa. Sedangkan yang mendapat nilai $\mathrm{D}$ ada $6,66 \%$ atau 2 siswa dan $\mathrm{E}$ tidak ada..

Pembelajaran pada siklus II menunjukkan semua siswa terlibat aktif dalam kegiatan pembelajaran. Hal ini dikarenakan siswa sudah mampu berkomunikasi dengan baik antar sesama anggota kelompok dan bisa memberi pendapat untuk informasi yang disampaikan kelompok lain. Antara siklus I dengan siklus II juga terjadi perubahan secara signifikan, hal ini ditandai dengan peningkatan jumlah siswa yang mencapai ketuntasan belajar. Hasil tes akhir siklus II ternyata lebih baik dibandingkan dengan tes akhir pada siklus I.

Dengan melihat perbandingan hasil tes siklus I dan siklus II ada peningkatan yang cukup signifikan, baik dilihat dari ketuntasan belajar maupun hasil perolehan nilai 
rata- rata kelas. Dari sejumlah 30 siswa masih ada 11 siswa yang belum mencapai ketuntasan, hal ini memang kedua siswa tersebut harus mendapatkan pelayanan khusus, namun sekalipun 11 siswa ini belum mencapai ketuntasan, di sisi lain tetap bergairah dalam belajar, sehingga dapat disimpulkan bahwa melalui penerapan pembelajaran menggunakan model GI dapat meningkatkan hasil belajar.

Secara umum dari hasil pengamatan dan tes sebelum pra siklus hingga siklus II, dapat disimpulkan bahwa penerapan model GI dapat meningkatkan hasil belajar siswa kelas X SMA Negeri 1 Sungai Mas pada materi Prinsip-prinsip Penelitian Sejarah yang diajarkan pada semester ganjil tahun pelajaran 2016/2017

\section{Simpulan dan Saran}

Berdasarkan penelitian ini dapat disimpulkan bahwa penerapan pembelajaran model GI dapat meningkatkan hasil belajar mata pelajaran Sejarah bagi siswa kelas X Semester genap tahun ajaran 2016/2017 SMA Negeri 1 Sungai Mas. Pada akhir siklus I, siswa yang mencapai ketuntasan belajar sebanyak 63,33\% (19 siswa), dan siswa yang belum tuntas sebanyak 36,66\% (11 siswa), sedangkan pada akhir siklus II, sebanyak 93,33\% (28 siswa) dan sebanyak 6,66\% (2 siswa) belum mencapai ketuntasan belajar. Adapun hasil non tes pengamatan proses belajar menunjukkan perubahan siswa lebih aktif selama proses pembelajaran berlangsung.

Berdasarkan penelitian yang telah dilakukan, peneliti mengajukan beberapa saran sebagai berikut :1) Disarankan kepada guru agar tidak hanya menerapkan metode konvensional yaitu ceramah, guru juga perlu menggunakan model yang lain seperti GI untuk membangkitkan minat belajar siswa dan memotivasi siswa dalam belajar. 2) Diharapkan dari hasil penelitian untuk selanjutnya dapat diaplikasikan untuk materimateri pokok pelajaran Sejarah yang lainnya.

\section{Daftar Pustaka}

Anni, Catharina Tri,dkk. (2007). Psikologi Belajar. Semarang: UPT MKK UNNES.

Johar, R., Nurfadhilah, dan L. Hanum. (2006). Strategi Belajar Mengajar. Banda Aceh : FKIP Universitas Syiah Kuala.

Hamalik, Oemar. (2003). Metode Mengajar dan Kesulitan-Kesulitan Belajar. Bandung: Tarsito.

Sanjaya, W. (2007). Strategi Pembelajaran Berorientasi Standar Proses Pendidikan. Jakarta: Kencana Prenada Media Group.

Suprijono. (2009). Cooperative Learning (Teori \& Aplikasi PAIKEM). Yogyakarta: Pustaka Pelajar.

Suryanto A, Haryanta A. (2006). Sejarah Kelas X: Jakarta. Erlangga.

Widodo. (2009). Strategi Belajar Mengajar. Jakarta. Rineka Cipta.

Zulmaulida, R., Saputra, E. (2014). Pengembangan Bahan Ajar Program Linear Berbantuan Lindo Software. Infinity Jurnal, 3(2), 189-216. Doi: https://doi.org/10.22460/infinity.v3i2.63. 